\title{
PRAKTIK SOSIAL DAN DINAMIKA PENDIDIKAN DI PONDOK PESANTREN
}

\author{
Dwi Astutik \\ Program Studi Pendidikan Sosiologi Antropologi FKIP UNS \\ dwiastutik@staff.uns.ac.id
}

\begin{abstract}
Abstrak
Tujuan dari penelitian ini untuk mengetahui dinamika interaksi dan perilaku sosial seharihari santriwati di dalam pondok pesantren yang tidak terlepas dari nilai, norma, dan budaya keluarga serta lingkungan di sekitar santriwati. Metode fenomenologi dipilih karena berusaha memahami pemahaman aktor terhadap fenomena yang muncul dalam kesadarannya, serta fenomena yang dialami oleh informan dan dianggap sebagai entitas yang ada di dunia. Tidak hanya keluarga yang memberikan pengaruh pada interaksi dan perilaku (I dan Me) santriwati, keberadaan lingkungan yang terdiri dari lingkungan pondok pesantren, teman sebaya, sekolah, internet termasuk di dalamnya media sosial memberikan pengaruh yang besar. Dialektika "l" berupa kehendak yang sering bertentangan dengan "Me" berupa norma sosial pondok pesantren, banyak dipengaruhi society yang merupakan faktor struktural. Ketika "I" bekerja lebih kuat dibandingkan "Me", mind dalam diri santriwati memilih untuk melakukan perilaku sosial yang cenderung melanggar norma sosial pondok pesantren seiring pengaruh dan interaksi terus menerus antara self, mind dan society.
\end{abstract}

Kata kunci : Pendidikan Pesantren, Santriwati, Pondok Pesantren

Abstract

The aim of this research to determine the dynamics of interaction and social behavior of students in the Islamic boarding school which is inseparable from values, norms, environment and family culture. The phenomenological method was chosen because it tries to understand the actor's understanding of the phenomena that appear in his consciousness, as well as the phenomena experienced by informants and are considered as entities that exist in the world. Not only the family which has an influence on the interaction and behavior (I and $\mathrm{Me}$ ) of the students, the existence of environment (Islamic boarding school environment, peers, school, the internet including social media has a big influence. Dialectic "I" in the form often contradicts "Me" in the form of the social norms of Islamic boarding schools, much influenced by society which is a structural factor. When "I" works stronger than "Me", the mind in the santriwati chooses to engage in social behavior that tends to violate the social norms of the Islamic boarding school as the influence and continuous interaction between self, mind and society.

Keywords : Islamic boarding school education, Female Students, Islamic Boarding School

\section{Pendahuluan}

Fenomena banyaknya para orang tua yang memberikan pendidikan bagi anak-anak mereka melalui lembaga pondok pesantren, salah satunya Pesantren Tebuireng merupakan daya tarik bagi peneliti. Peneliti tertarik karena banyak para orang tua yang memberikan pendidikan bagi anak melalui lembaga pendidikan pondok pesantren Tebuireng dengan harapan anak mereka akan menjadi pribadi yang baik, bermoral, dan dapat bertanggung jawab pada diri sendiri, masyarakat dan khususnya Tuhan Yang Maha Esa. Pondok pesantren menjadi alternative pendidikan bagi orang tua yang memiliki keterbatasan dan kegagalan dalam pemberian pendidikan pengetahuan agama bagi putra putrinya (Marjuki dan Masrukin, 2019: 3). Akan tetapi, kenyataan di lapangan mengatakan bahwa banyak para santri 
khususnya para santriwati yang berperilaku menyimpang dan jauh dari harapan orang tua mereka.

Fakta di lapangan yang ditemukan penulis mengatakan bahwa banyak para santriwati yang berkelakuan kurang baik bahkan bisa dikatakan menyimpang dari nilai dan norma yang sudah ditetapkan dalam pondok pesantren. Perilaku para santri yang menyimpang dari nilai dan norma yang sudah ditentukan dalam pondok pesantren dapat dicontohkan dengan tindakan memakai dan mencuri barang teman antara santriwati yang satu dengan yang lain dalam satu kamar maupun asrama.

Perilaku lain yang dapat ditemui di lapangan adalah keluar dari pondok pesantren ketika ada kelas untuk belajar (membolos). Masalah lain yang tidak bisa diabaikan dan banyak menimbulkan perilaku menyimpang adalah adanya peraturan pondok pesantren untuk tidak berkomunikasi dengan lawan jenis. Masa remaja adalah masa dimana anak masih mencari jati dirinya dengan banyak mencoba pergaulan dengan teman-teman mereka termasuk pertemanan dengan lawan jenis. Akan tetapi, dengan tinggal dan menjadi santriwati di pondok pesantren, bersedia atau tidak bersedia para santriwati harus mematuhi peraturan yang sudah ditetapkan oleh pihak pondok pesantren, salah satunya adalah tidak diperbolehkan adanya komunikasi dan pergaulan dengan lawan jenis, terlebih di dalam pondok pesantren. Setiap hari santriwati akan tinggal dan berkomunikasi dengan sesama jenis. Keadaan ini yang banyak menimbulkan tekanan dalam diri para santriwati, sehingga memunculkan banyak perilaku yang tidak sedikit memberontak terhadap peraturan pondok pesantren dan banyak mengarah pada tindakan menyimpang. Fenomena ini dapat dicontohkan dengan banyaknya para santriwati keluar yang berkomunikasi dengan teman atau santri laki-laki dengan menggunakan media sosial atau melalui facebook dibandingkan dengan mengikuti kegiatan ekstrakurikuler. Dengan menggunakan media sosial seperti facebook para santri. dapat secara bebas melakukan komunikasi secara tidak langsung dengan siapa saja yang menjadi teman mereka.

Sikap para santri yang berperilaku kurang baik bahkan menyimpang tentu terdapat alasan mengapa mereka bertindak menyimpang dan tidak sesuai dengan nilai dan norma yang berlaku dalam pondok pesantren bahkan jauh dari harapan orang tua mereka. Bertolak pada latar belakang yang telah dideskripsikan, maka permasalahan penelitian ini meletakkan pada bagaimana perilaku dan interaksi sosial para santriwati dalam pondok pesantren Tebuireng Jombang dilihat dalam perspektif Mead.

\section{Metode}

Penelitian ini menggunakan studi kasus dengan pendekatan analisis kualitatif dengan metode fenomenologi. 
Pendekatan penelitian analisis kualitatif merupakan pendekatan penelitian kualitatif yang tidak hanya ingin mendeskripsikan fenomena apa yang terjadi dalam sebuah masyarakat, akan tetapi lebih dari itu, pendekatan ini memperhatikan aspek-aspek penting yang membedakan dengan pendekatan deskriptif kualitatif, yakni tidak berhenti pada bagaimana suatu fenomena bisa terjadi dalam masyarakat, akan tetapi ingin mengupas lebih dalam mengapa suatu fenomena bisa terjadi. Metode fenomenologi digunakan dalam penelitian ini. Schutz (dalam Ritzer, 2004:60) beranggapan bahwa dunia sosial keseharian senantiasa merupakan suatu yang intersubyektif dan pengalaman penuh makna. Dengan demikian fenomena yang ditampakkan oleh individu merupakan refleksi dari pengalaman transendental dan pemahaman tentang makna atau verstehen. Fenomenologi dalam bekerjanya akan selalu berusaha memahami pemahaman aktor terhadap fenomena yang muncul dalam kesadarannya, serta fenomena yang dialami oleh informan dan dianggap sebagai entitas yang ada di dunia.

Penelitian yang dilakukan di Pondok Pesantren Tebuireng ini menggunakan sumber data berupa data data primer didapatkan melalui wawancara baik terstruktur maupun tidak testruktur dan data hasil observasi secara aktif dalam mengamati perilaku sosial santriwati sehari-hari di pondok pesantren. Data sekunder yang digunakan berupa dokumentasi yang relevan dengan masalah penelitian, yakni berupa dokumentasi mengenai tata tertib dalam pondok pesantren dan kegiatan santriwati dalam pondok pesantren. Sedangkan jenis data dalam penelitian ini adalah berupa transkrip wawancara, catatan lapangan berupa catatan hasil observasi, dan dokumentasi foto. Dengan demikian, maka penentuan informan dalam penelitian ini yan dipilih yakni santriwati, orang tua dan pembina pondok pesantren.

Proses pengumpulan data dalam penelitian ini dilakukan melalui observasi secara aktif dengan keikutsertaan peneliti dalam kegiatan pondok pesantren. Kemudian, peneliti dengan aktif mencoba mendekati dan berbicara secara intens santriwati termasuk orang tua yang mengunjungi mereka pada hari libur, khususnya santriwati yang melanggar nilai dan norma pondok pesantren.

Setelah melakukan proses pengumpulan data, maka langkah selanjutnya adalah teknik analisis data. Teknik analisis data yang dilakukan meliputi hasil observasi, interview mendalam, dan studi pustaka yang relevan dibuat kategori-kategori dan diidentifikasi sesuai dengan karakteristik masingmasing. Kemudian, dari beberapa kategori yang sudah dibuat, dilakukan analisis yang berpijak pada kerangka konseptual yang sudah dituliskan.

\section{Hasil dan Pembahasan}




\section{Keluarga dan Interaksi Serta Perilaku Sosial Santriwati}

Menurut Cooley (dalam Ritzer, 2004:289) dalam sosialisasi menyangkut perkembangan diri, menyimpulkan bahwa manusia berkembang karena diciptakan oleh masyarakat melalui interaksi dengan orang lain. Seperti halnya perkembangan pada diri santriwati, pada saat anak-anak, mereka banyak menghabiskan waktu dengan keluarga mereka dan lingkungan sekitar. Dalam pondok pesantren, jelas tidak sama baik peraturan maupun anggota yang ada di dalamnya, dan anak melalui sebuah proses sosialisasi kembali tidak seperti ketika mereka kecil dan dikenalkan nilai dan norma oleh anggota keluarga. Akan tetapi, mereka masingmasing sudah memiliki nilai dan norma yang mereka bawa ke lingkungan baru mereka.

Pada dasarnya, keluarga memang memiliki pengaruh yang besar dalam membentuk perilaku anak, karena melalui keluarga anak belajar mengenal masyarakat dimana la tinggal, mengenal nilai dan budaya keluarga yang nantinya akan berpengaruh ketika mereka berada di luar keluarga mereka (Berns, 2007:47). Bisa jadi bahwa perilaku mereka seharihari dalam pondok pesantren adalah cermin dari apa yang mereka peroleh ketika mereka mendapatkan pengenalan sebuah aturan main dalam kehidupan yang diberikan kepada mereka melalui keluarga semasa mereka kecil. Terlebih lagi keberadaan orang tua merupakan model yang ditiru oleh anak-anak mereka dan sebagai panutan bagi anak dalam memutuskan apa yang dirasa baik dan perlu bagi kehidupan sang anak.

Melalui pondok pesantren, orang tua tidak perlu cemas lagi akan kebutuhan pendidikan dan pengawasan bagi anakanak mereka, terlebih bagi mereka yang sibuk dengan urusan pekerjaan dan karir. Tuntutan pekerjaan banyak menjadi pendorong utama mengapa para orang tua lebih senang ketika anak-anak mereka belajar dan tinggal dalam pondok pesantren. Keinginan untuk tetap memberikan pendidikan bagi anak-anak mereka dan sekaligus tetap mendapatkan kontrol sudah menjadi alasan pasti mengapa orang tua menginginkan anakanak mereka belajar dan tinggal di pondok pesantren. Dalam keadaan seperti ini, tidak sedikit anak yang mengorbankan cita-citanya (I) dan dengan terpaksa menuruti keinginan dari para orang tua mereka sebagai (Me) dalam diri mereka.

Peran orang tua terkait dengan interaksi dan perilaku sosial anak seharihari mencakup bagaimana mereka memperoleh pengasuhan dari orang tua mereka. Keadaan dalam keluarga terkait ekonomi orang tua, pendidikan orang tua serta keadaan terkait harmonis tidaknya keluarga (brokenhome) turut memberikan pengaruh yang besar dalam membentuk perilaku anak di lingkungan luar.

a. Perceraian orang tua

Seperti yang dijelaskan oleh Amato, Kelly dan Emery (dalam Hughes, 2005) 
mengindikasikan bahwa terdapat beberapa risiko dari perceraian yang dapat memberikan pengaruh yang tidak baik pada anak, antara lain hilangnya pengasuhan orang tua, berkurangnya pemenuhan kebutuhan ekonomi, tuntutan hidup yang lebih menekan anak, kesehatan mental yang rendah pada anak karena anak harus memilih untuk tinggal dengan ayah atau ibunya, mempengaruhi perkembangan anak, dan berkurangnya kesejahteraan anak karena orang tua yang berkonflik sehingga anak tidak menemukan kenyamanan dalam keluarga mereka.

Dari data yang diperoleh dalam penelitian, dapat disimpulkan bahwa santriwati yang memiliki keluarga yang tidak utuh atau brokenhome sebagai society dalam kehidupan mereka, cenderung untuk melakukan perilaku yang banyak menyita perhatian orang lain di lingkungannya, dan tidak sedikit yang mengarah pada perilaku yang cenderung melanggar nilai dan norma pondok pesantren. Hal ini dikarenakan, menurut Mead (dalam Ritzer, 2004) dalam self anak kurang mendapatkan perhatian dan kasih sayang dari sosok sang ayah, karena ketika bercerai, anak tinggal dan hidup dengan sang ibu beserta keluarga barunya. Terlebih lagi, ketika anak tidak dekat dengan sang ibu dan kurang mendapat perhatian karena sang ibu sibuk bekerja, maka anak akan mencoba mencari perhatian dari orang lain sebagai wujud mind yang ada dalam diri mereka.
Sehingga, apa yang kemudian diungkapkan oleh Amato, Kelly dan Emery (dalam Hughes, 2005) adalah memang ditemukan di lapangan bahwa anak yang mengalami dan berada dalam keluarga yang tidak utuh atau brokenhome, maka "I" dalam diri anak akan cenderung tertekan oleh "Me" dan terwujud dari berbagai dinamika perilaku mereka, termasuk di dalamnya perilaku mereka yang menyimpang. Society (keluarga dan lingkungan pondok pesantren) memberikan pengaruh yang kuat dalam kehendak "Me" dalam diri, sehingga pergolakan antara "l" dan "Me" banyak dimenangkan oleh "Me" sebagai pemecahan masalah (mind) dalam diri. "Me" yang mengandung kontrol berupa norma sosial pondok pesantren memenangkan pertarungannya atas "I", sehingga yang terbentuk dalam self adalah kehendaknya untuk kabur dari pondok pesantren yang didorong oleh faktor struktural (keadaan keluarga yang tidak nyaman). Selain faktor struktural berupa perceraian dalam sebuah keluarga, ekonomi keluarga juga tidak kalah penting dalam menentukan perilaku anak.

\section{b. Ekonomi}

Tidak hanya keadaan keluarga yang harmonis atau sebaliknya yang memberikan pengaruh bagi pembentukan kepribadian dan perilaku anak, akan tetapi keadaan ekonomi keluarga termasuk memberikan pengaruh pada apa yang akan dilakukan anak dalam 
pengembangan diri mereka (Berns, 2007:42.

Verzat dan Wolf (dalam Gudmuson dan Danes, 2011) menyebutkan bahwa orang tua dengan status dan pendapatan ekonomi yang tinggi, lebih berpeluang besar untuk memenuhi kebutuhan dan memberikan ajaran melalui contoh pada hal yang lebih luas. Keadaan orang tua yang bisa dikatakan dalam ekonomi kelas menengah kebawah jelas berbeda dengan anak yang dibesarkan dalam keluarga dengan ekonomi kelas menengah dan menengah atas, meskipun hal ini bukan menjadi jaminan yang mutlak. Keterbatasan orang tua ditambah dengan kurangnya fungsi afeksi yang diberikan pada anak, tentu akan memberikan efek negatif pada perilaku mereka dalam kehidupan sehari-hari mereka, khususnya dalam pondok pesantren. Perilaku yang negatif itu misalnya saja mencuri karena keterpaksaan yang disebabkan belum datangnya kiriman uang dari orang tua santriwati dan kurangnya perhatian pada mereka.

Santriwati dengan kemampuan ekonomi orang tua memadai, dan memperoleh uang saku yang tidak pernah telat setiap bulannya, maka kemungkinan besar anak tidak akan pernah memiliki masalah dengan keuangan dan kebutuhan mereka. Sesuai dengan salah satu fungsi dasar sebuah keluarga, yakni fungsi ekonomi. Dalam hal ini keluarga khususnya orang tua berkewajiban memenuhi dan menyediakan tempat tinggal, perlindungan dan memenuhi kebutuhan akan konsumsi kepada anak (Berns, 2007: 81).

Seperti yang diungkapkan oleh Bernstein dan Bradley (dalam Berns, 2007) bahwa berbeda dengan anak yang memiliki keluarga khususnya orang tua dengan pendapatan dan ekonomi menengah dan menengah ke atas, dalam mendidik anak orang tua banyak menggunakan contoh di lingkungan sekitar dalam mengembangkan diri anak. Sehingga, anak anak dapat berkembang secara luas dengan adanya hadiah dan penghargaan atas dirinya dalam budaya dan norma keluarga.

Ketika keluarga secara finansial memiliki keterbatasan dalam memenuhi kebutuhan anak, dan ketika orang tidak mau tau dengan hal tersebut, maka yang terjadi adalah anak mencari jalan keluar asal la mampu bertahan dalam lingkungan sosial mereka. Seperti yang diungkapkan oleh Mead (dalam Ritzer, 2004) bahwa individu belum menjadi anggota masyarakat (society) yang seutuhnya, jika individu belum mampu hidup seperti komunitasnya. Dorongan "I" untuk menjadi anggota dalam lingkungan pertemanan, kemudian mendorong "Me" tidak terlalu kuat dalam mengkontrol anak. Sehingga, yang berpengaruh kuat dalam membentuk self dan mind anak adalah pengaruh lingkungan luar di sekelilingnya. Hal lain yang tidak dapat diabaikan dalam membentuk perilaku anak selain keadaan keluarga terkait keharmonisan dan 
finansial, faktor struktural lain adalah pendidikan yang dimiliki orang tua.

c. Pendidikan

Rizwan dkk (2014) menjelaskan bahwa anak yang memiliki orang tua berpendidikan tinggi, akan memberikan arahan masa depan dan membentuk kepribadian yang baik bagi anak. Dan sebaliknya, pendidikan orang tua yang kurang akan memberikan sedikit wawasan bagi anak. Akan tetapi, berdasarkan hasil lapangan baik melalui observasi dan wawancara secara mendalam, orang tua yang berpendidikan tinggi memang memberikan motivasi dan pengaruh baik bagi anak, tapi ada juga orang tua yang memiliki pendidikan tinggi justru tidak memahami apa yang sesungguhnya diinginkan dan dibutuhkan oleh anaknya. Dengan kata lain tidak semua orang tua yang berpendidikan tinggi mampu memberikan motivasi dan arahan yang baik bagi anak mereka di pondok pesantren. Kehendak orang tua yang terlalu memaksakan self anak, banyak memberikan pengaruh pada mind yang dipilih oleh sang anak.

Hasil penelitian Duncan dan Magnuson (dalam Berns, 2007) menyebutkan bahwa status sosial ekonomi yang di dalamnya termasuk pendidikan (orang tua dengan lulusan sekolah menengah atas dan perguruan tinggi), memiliki tingkat kognitif yang tinggi. Ramsey (dalam Berns, 2004) juga menyebutkan bahwa sesuai dengan lingkungan anak dengan orang tua yang memiliki pendidikan tinggi yang selalu berdasar pada budaya dan norma yang dijunjung tinggi, anak dididik untuk menjadi individu yang berorientasi pada kemajuan hidup yang ditunjukkan dengan harapanharapan memperoleh penghargaan atas apa apa yang sudah dicapai dalam lingkungannya.

Kehendak orang tua yang terlalu memaksakan anak untuk bersedia belajar di pondok pesantren, mendorong "I" dari sang anak untuk mengikuti "Me" dari lingkungan sekitarnya. Ketika self dalam diri anak tidak mampu mengikuti aturan main dalam sebuah komunitas, maka mind yang dipilih adalah menunjukkan keberadaan self atau diri dengan cara yang lain. Bukan dengan menginternalisasi nilai dan noma komunitas (Ritzer, 2004:287-288) melainkan dengan melanggar nilai dan norma komunitas. Mind yang dipilih kemudian dijalankan atas paksaan kepada self anak dari orang tua mereka, dan anak menjalankan apa yang lingkungan katakan kepadanya.

Kesimpulannya adalah bahwa orang tua yang berpendidikan memang mampu memberikan arahan dan motivasi yang baik pada anak. Akan tetapi, ketika justru cenderung memaksa anak untuk menuruti dan mematuhi keinginan orang tua, justru akan menggiring anak untuk melakukan perilaku yang kurang baik di dalam lingkungannya, karena bisa jadi perilaku yang dilakukan adalah sebagai resistensi dirinya karena tidak mampu menyesuaikan 
dengan lingkungan sekitarnya. Sehingga, tidak jarang anak yang memang sengaja melakukan hal-hal yang menyimpang dari nilai dan norma yang ada dalam pondok pesantren. Hal ini justru dilakukan anak agar orang tua mereka mengerti bahwa keinginan anak yang sebenarnya adalah tidak ingin berada dalam pondok pesantren.

\section{Lingkungan dan Interaksi serta Perilaku Sosial Santriwati}

Selain keluarga, lingkungan sebagai faktor struktural dalam konsepsi Mead mengenai masyarakat (society), memiliki pengaruh yang cukup besar dalam membentuk kepribadian dan perilaku santriwati (self) anak. Hal ini dapat terjadi karena anak ketika mereka sudah mengenal individu lain selain anggota keluarga, dan hidup dalam lingkungan luar, maka perilaku dan kebiasaan mereka akan menyesuaikan dengan lingkungan dimana mereka tinggal. Hal ini seperti penjelasan Mead (dalam Ritzer, 2008:288) bahwa individu harus menginternalisasi nilai norma dalam masyarakat dimana la tinggal untuk dapat menjadi bagian diri dari masyarakat.

Lingkungan (society) tidak kalah pentingnya dengan keberadaan keluarga sebagai pembentuk dan mempengaruhi perkembangan anak melalui dialektika antara "I" dan "Me" dalam self anak. Anak dibentuk dan berinteraksi dengan lingkungan sosialnya melalui pergulatan antara "I" dan "Me" dalam dirinya. Melalui lingkungan sosial (society) yang menurut
Mead (dalam Ritzer, 2004) bahwa antara mind, self dan society saling mempengaruhi, anak dibentuk dan ditentukan kepribadian dan perilakunya melalui interaksi dan penyesuaian diri mereka dengan lingkungan sosial seharihari. Hal ini dapat dijelaskan bahwa keberadaan lingkungan pondok pesantren sebagai faktor struktural dalam masyarakat (society), yang kemudian banyak mempengaruhi "l" dan "Me" dalam diri anak, mampu menentukan pikiran (mind) yang akhirnya diambil oleh sang anak. Keberadaan lingkungan pondok pesantren yang begitu kuat, mampu menentukan pembentukan self dalam diri anak melalui proses sosial yang terus menerus dalam bentuk interaksi dan komunikasi yang terus menerus antara anak dengan lingkungan (Ritzer, 2008:281). Lingkungan yang luas, mencakup teknologi dalam hal ini media sosial, teman sebaya diantara sesama santriwati dan lingkungan sekolah mampu memberikan pengaruh dan dorongan yang besar dalam menentukan perilaku santriwati. Keberadaan teknologi berwujud media sosial seperti facebook, line dan instagram bukan hanya memberikan kemudahan dan pengetahuan yang semakin luas pada santriwati, akan tetapi juga memberikan efek yang negatif pada beberapa santriwati. Hal ini terjadi karena santriwati menggunakan internet dan media sosial bukan hanya untuk keperluan untuk mencari ilmu dan menunjukkan eksistensi di dalam pertemanan mereka, 
akan tetapi justru banyak dimanfaatkan untuk hal lain seperti bertemu dan menjalin hubungan dengan teman lawan jenis (berpacaran) di luar pondok pesantren. "I" yang begitu kuat untuk bertemu teman lawan jenis mereka tanpa diimbangi dengan "Me" dalam diri santriwati yang mencakup nilai dan norma pondok pesantren mampu mendorong mind untuk melakukan apa yang "I" inginkan.

3. Generalized Other, Resosialisasi dan Kehidupan Remaja dalam Pondok Pesantren

Resosialisasi adalah proses dimana individu belajar norma, nilai, atitude dan perilaku yang baru. Resosialisasi biasanya terjadi ketika kita belajar sesuatu yang bertentangan dengan pengalaman sebelumnya, dalam hal ini anak mengalami sebuah proses resosialisasi ketika mereka keluar dari lingkungan keluarga dan harus menyesuaikan dengan nilai dan norma yang baru dalam pondok pesantren. Santriwati tidak lagi hidup dalam sebuah keluarga mereka selama mereka kecil hingga remaja, akan tetapi hidup dan menjadi satu kelompok menjadi santriwati dalam pondok pesantren. Di dalam pondok pesantren, anak dapat menemukan pengalaman baru yang sebelumnya belum pernah dialami individu. Goffman menggunakan term institusi total yang mengacu pada tempat seperti penjara, kampus dan sekolah sebagai tempat dimana individu dapat menghilangkan nilai dan norma yang terdapat dalam masyarakat, dan hampir sepenuhnya berada dalam kontrol dalam sebuah institusi (Saylor Academy, 2015:25). Seperti yang dikatakan oleh Goffman, bahwa dalam hal ini pondok pesantren mampu mendorong individu untuk menghilangkan nilai dan norma yang mereka dapat selama mereka berada dan hidup dalam keluarga mereka dan menggunakan nilai dan norma baru sebagai hasil dari penyesuaian diri mereka terhadap nilai dan norma yang berada dalam pondok pesantren (Saylor Academy, 2015:25).

Institusi pendidikan seperti halnya pondok pesantren yang betindak sebagai society, memang dapat secara efektif mengisolasi anak remaja dari pengaruh dan informasi dari luar, mengatur aktivitas mereka, menekan peran, status dan norma yang sudah didapat sebelumnya dalam sebuah keluarga. Kemudian, menggantinya dengan nilai dan norma yang baru dan berlaku dalam sebuah pondok pesantren dalam "Me" anak. Selain itu, nilai dan norma yang diberlakukan dalam sebuah pondok pesantren dapat mengontrol perilaku individu di dalamnya dengan hadiah dan hukuman (Saldana, 2013:229). Terlebih ketika remaja, masa dimana "l" atau kehendak anak menginginkan hal yang baru yang belum pernah mereka alami sebelumnya sebagai konsekuensi semakin luasnya hubungan sosial anak dengan individu yang lain dalam lingkungan pondok pesantren (society). 
Dengan anak memasuki usia remajanya di dalam pondok pesantren, maka perkembangan kepribadian dan perilaku anak akan banyak dipengaruhi oleh lingkungan pondok pesantren dengan beragam nilai dan norma serta budaya yang berlaku dalam sebuah pondok pesantren dibandingkan dengan nilai dan norma yang sudah mereka peroleh melalui sosialisasi dalam keluarga mereka. Menurut Mead (dalam Ritzer, 2004) Society berupa lingkungan pondok pesantren memiliki andil dalam membentuk self dan mind anak. Ketiganya tidak dapat dipisahkan dan saling bertautan.

Pondok pesantren yang mampu mengisolasi individu dari pengaruh dan informasi dari luar, mengatur aktivitas mereka, menekan peran, status dan norma yang sudah didapat sebelumnya dalam sebuah keluarga dan menggantinya dengan nilai dan norma yang baru, dan mengontrol perilaku individu di dalamnya dengan hadiah serta hukuman tidak ditemukan dalam realita di lapangan. Santriwati memang terisolasi secara tempat tinggal dengan keluarga dan teman-teman mereka secara luas, akan tetapi meskipun hidup dan tinggal dalam pondok pesantren dengan segala peraturan atau nilai dan norma yang banyak mengekang, mengontrol tingkah laku serta tutur kata dalam setiap kesempatan, tidak membatasi para santriwati untuk mendapatkan dan menghabiskan waktunya dengan dunia luar. Seperti halnya anak remaja pada umumnya, santriwati mendapatkan sebuah infomasi yang tidak terbatas, salah satunya melalui internet. Melalui internet, para santriwati tidak hanya mampu mengakses dan mencari berita apa saja yang mereka inginkan seiring dengan semakin menjamurnya $K$-pop yang tidak hanya melanda anak-anak di sekolah umum, akan tetapi juga mengena pada anak-anak santriwati dalam pondok pesantren. Melalui internet pula, para santriwati mampu terhubung dengan teman-teman mereka tanpa ada jarak, batas dan waktu dan tidak terbatas pada teman perempuan, melainkan teman lakilaki. Tidak hanya itu, melalui internet pula para santiwati dapat mengenal dan ingin mencoba dengan hal yang kita kenal sebagai berpacaran dan bertemu dengan teman laki-laki mereka yang tentu saja hal ini bertentangan dengan nilai dan norma pondok pesantren.

Keterbatasan mereka berada dalam pondok pesantren dengan nilai dan norma yang harus mereka patuhi dalam "Me" mereka, memang terkadang bukan menjadi hal yang menjadikan anak patuh dan baik, akan tetapi sebaliknya, menjadi pendorong anak untuk semakin tahu dan penasaran dalam "I" mereka dengan apa yang dilarang oleh lingkungan pondok pesantren dimana mereka tinggal sebagai faktor struktural (society) yang berpengaruh. Ketika mereka berada di rumah, anak dapat secara bebas mengenal dunia dan lingkungan luar 
seperti teman laki-laki meskipun hanya teman di dalam kelas. Anak bisa menonton televisi secara leluasa di dalam rumah meskipun beberapa dari mereka tetap dalam pengawasan orang tua mereka, anak dapat bermain handphone dan mengakses apapun yang mereka inginkan, dan anak dapat secara leluasa untuk keluar rumah. Akan tetapi, kebiasaan di rumah ini justru berbanding terbalik dengan nilai dan norma serta budaya yang diterapkan dalam pondok pesantren. Santriwati di dalam pondok pesantren, jauh dari dengan kebiasaan dirumah seperti menonton televisi, membuka handphone, bertemu teman laki-laki dan keluar dari rumah untuk bermain. Penyesuaian akan nilai dan norma yang baru tentu akan terjadi pada diri anak sebagai konsekuensi anak hidup dalam lingkungan baru, yakni pondok pesantren.

Ketika anak belajar dan mempelajari sesuatu dari lingkungan, maka anak semakin memiliki banyak cara untuk bertahan di dalam lingkungannya. Ketika lingkungan di sekolah (society) mendorong dan menuntut secara kuat "I" mereka untuk menunjukkan identitas diri sebagai remaja pada umumnya dengan berpacaran, didukung dengan semakin mudahnya akses para santriwati untuk mengenal dan berkomunikasi dengan teman laki-laki mereka, maka perilaku yang dipilih akan banyak menggunakan "I" dibandingkan "Me". "l" berupa kehendak mendorong santriwati agar mampu menunjukkan eksistensi diri dan sekaligus popularitas mereka dihadapan teman-teman mereka (Berns, 2007: 42).

Dialektika antara "l" dan "Me" dalam pembentukan self santriwati ketika dimenangkan oleh "l" berupa kehendak spontanitas dan keinginan, maka "Me" berupa nilai dan norma sosial pondok pesantren banyak disepelekan. Mind sebagai jalan keluar bagi anak untuk tetap dapat bertahan dilingkungan atau society membentuk perilaku santriwati baik yang menyimpang (melanggar norma) atau sebaliknya sesuai dengan norma. Tidak hanya terbatas pada perilaku-perilaku serta interaksi mereka yang positif, tetapi perilaku dan interaksi yang mengarah pada hal negatif juga dilakukan oleh santriwati dalam pondok pesantren di dalam kesehariannya.

\section{Simpulan}

Perilaku sosial yang melanggar norma sosial dalam pondok pesantren disebabkan adanya pergolakan antara "I" dan "Me" dalam self santriwati. Self yang terdiri dari "I" dalam bentuk kehendak dan "Me" yang berbentuk kontrol diri sesuai keadaan lingkungan, banyak dipengaruhi oleh faktor struktural berupa lingkungan pondok pesantren dan keluarga. Kehendak dalam bentuk "I" dalam diri, terkait dengan motivasi dalam diri, selalu beradu dengan "Me" dalam diri. Anak yang berkehendak untuk bersekolah di luar dalam "I" nya, harus menyesuaikan dengan "Me" dalam dirinya berupa 
keinginan dan paksaan orang tua yang tercakup dalam faktor struktural berupa keluarga. Self kemudian berkembang dan menentukan pemecahan masalah dengan pemikirannya (mind) seiring dengan interaksi dan komunikasi anak dengan lingkungan sosialnya (society).

Faktor struktural yang mampu mempengaruhi perkembangan diri (self) anak antara lain keadaan keluarga dan lingkungan. Keluarga (society) dengan ekonomi kurang, dengan selalu terbatas memberikan uang saku pada anak, membuat anak mencari jalan keluar (berpikir atau mind) dengan mengambil uang milik temannya ketika terdapat peluang. Tidak hanya dalam segi ekonomi, keadaan keluarga yang brokenhome juga menjadi pendorong mengapa anak melakukan perilaku menyimpang. Tidak adanya perhatian dari orang tua, orang tua terlalu sibuk mencari uang, menyebabkan anak menggunakan mind dalam dirinya untuk mencari perhatian di lingkungan sosialnya. Ketika anak tidak merasa nyaman dalam keluarganya, maka anak akan mencari kehidupan senyaman mungkin di luar lingkungan keluarga mereka, tanpa memperhatikan nilai dan norma apa yang mengikat mereka. "Me" yang sejatinya menjadi kontrol dalam diri anak, tidak mampu mempengaruhi "I" untuk berperilaku sesuai dengan norma sosial disekelilingnya.

Lingkungan (society) yang terdiri dari lingkungan pertemanan, sekolah, terutama dengan adanya media sosial berupa facebook, line dan instagram serta kemudahan mengaksesnya juga menjadi poin penting dalam menentukan self anak. Lingkungan teman sebaya (society) mampu mendorong perilaku anak (I) untuk mengikuti dunia yang mereka bentuk sendiri, terlebih ketika mereka sudah berkelompok, maka dunia mereka seolah berbeda dengan dunia teman yang lain. Keberadaan faktor lain seperti media sosial berupa facebook, line dan instagram mampu sebagai media bagi santriwati untuk mengenal dan menjalin hubungan dengan teman lawan jenis mereka. Tidak heran, banyak dari beberapa santriwati yang mengenal pacar mereka melalui media sosial berupa facebook, line dan instagram. Dari sinilah kemudian mereka mencoba cara sebisa mungkin untuk mencari kesempatan dengan menggunakan mind untuk bertemu dengan pacar mereka, tak jarang kemudian banyak melakukan kecenderungan berperilaku menyimpang dari nilai dan norma pondok pesantren seperti kabur dari pondok pesantren. Dari sini, antara mind, self dan society tidak dapat dipisahkan satu sama lain dalam membentuk perilaku anak. Ketika dalam diri santiwati mendapati suatu kehendak "I" dan dibatasi dengan adanya "Me" dalam dirinya berupa kontrol sosial dalam bentuk norma sosial sekelilingnya, maka pergulatan antara "I" dan "Me" dalam diri santriwati akan semakin hebat ketika faktor struktural berupa keluarga dan lingkungan (society) memberikan 
pengaruh yang besar. Dengan keadaan society yang ada dalam lingkungan santriwati, maka jalan keluar atas apa yang dialami menjadi jalan keluar (mind) bagi diri santriwati sebagai hasil pergulatan antara "I" dan "Me" dalam self.

\section{Ucapan Terima Kasih}

Penulisan artikel yang merupakan hasil penelitian yang dilakukan oleh peneliti tidak akan menghasilkan sebuah tulisan tanpa ikut campur tangan dari sejawat dan orang penting dalam perolehan data penelitian. Pengurus pondok pesantren Tebu Ireng Al-Farros, pengasuh santriwati dan santriwati adalah sumber primer dalam pemerolehan data di lapangan. Kehangatan yang diberikan selama peneliti tinggal di pondok pesantren untuk mencari data, sangat memudahkan peneliti dalam pencarian jawaban akan masalah penelitian yang diambil. Tidak lupa ucapan terima kasih diberikan kepada Prof.Dr. Tadjuddin Noer Effendi, yang tidak pernah lelah melakukan koreksi dan review terkait dengan hasil penelitian, sehingga dapat dimanfaatkan oleh penulis untuk menghasilkan sebuah karya ilmiah yang bermanfaat. Terakhir, rekan sejawat dan redaksi Jurnal Dimensia yang bersedia memberikan kesempatan dan peluang bagi penulis untuk memberikan sedikit sumbangsih dalam penulisan artikel ilmiah.

\section{Daftar Pustaka}

Denzin, Norman K \& Lincoln, Yvonna S, 1994. The SageHandbook of Qualitative Research (terjemahan), Thousand Oaks, California, SAGE Publications.

(2011). The SageHandbook of Qualitative Research (terjemahan), Yogyakarta: Pustaka Pelajar

Fansuri, Novicha Zayantinoor. (2014). Pengaturan Privasi Komunikasi Santriwati pada Aktivitasnya di Media Sosial Facebook di Pondok Pesantren Modern Wilayah Jombang, skripsi tidak dipublikasikan, fakultas IImu Sosial dan IImu Politik, Universitas Pembangunan Nasional "VETERAN" Jawa Timur.

Mead, George H, Socialization and Social Interaction Throughout the Life Course dalam Essentials of Sociology, Lindsley Linda $\mathrm{L}$ and Beach Stephen, Prentice Hall.

Rizwan, M, Rehman, Adeel Ur, dan Shabbir. (2014). Explorative Study Of Parents Education Effect On The Socialization On Of Their Children (A Case of district Muzaffar Garh, Research and Humanitas and Social Sciences, Vol.4, No.26, Pp:81-86.

Ritzer, George. (2013). Sosiologi. Yogyakarta: Pustaka pelajar.

Ritzer, Goerge. 2011. Sociological Theory. America, New York: The McGrawHill Companies. Diakses 21 Agustus 2015, dari BookFi Database.

Ritzer, George. (2004). Sosiologi IImu Pengetahuan Berparadigma Ganda, Jakarta: PT.RajaGrafindo Persada.

Ritzer, George \& Goodman, Douglas J. (2004). Teori Sosiologi Modern. Jakarta: Kencana.

Ritzer, George. (2003). Sosiologi IImu Pengetahuan Berparadigma Ganda. Jakarta: PT. RajaGrafindo Persada.

Supraja, dkk. (2013). Alienasi, Fenomenologi, dan Pembebasan Individu. Yogyakarta : Lingkar Studi Mikrososiologi UGM.

Berns, Roberta M, (2007), Child, Family, School, Community, Socialization and Support, Wadsworth Cengage Learning, diakses 10 Januari 2016, dari BookFi Database. 
Gudmunson, Clinton dan Danes, Sharoon, (2011), Family Financial Socialization: THEOry and Critical Review, Journal of Family and Economic Issues, No. 33, Pp: 644667.

Lindsley and Beach, (2004), Socialization and Social Interaction Throughout Life Course, Essentials of Sociology, Pp:1-9.

Marjuki dan Masrukin, (2019), Motif Prang Tua Santri di Pondok Pesantren HM LIrboyo, Jurnal IAIT Kediri, Vol. 30; No 1, Pp: 166-181

Rummel, R.J. "Social Behavior and Interaction." dalam Understanding Conflict And War: Vol. 2: The Conflict Helix. Beverly Hills. CA: Sage Publications Database.

Saylor Academy. (2015). "Socialization." Diakses September 27, 2015 dari http://cnx.org/content/m43027/latest /?collection=col11407/1.7.

Saldana, Justin. (2013). Power and Conformity in Today's School, Journal of Humanities and Social Science. Vol. 3, No 1, Pp:228-232 